\title{
Comment on Hernandez-Vasquez et al., a bibliometric analysis of the global research on biosimilars
}

\author{
Hillel P. Cohen (D)
}

\begin{abstract}
A bibliometric analysis provided by Hernandez-Vasquez et al. listed the institutions that have published most extensively in the field of biosimilars. Sandoz and Novartis International were considered as separate entities, but are both are divisions of the same parent company. When considered as a single entity for purposes of tracking publications, Sandoz-Novartis is among the leaders in the number of articles published about biosimilars.
\end{abstract}

Keywords: Bibliometric analysis, Biosimilar, Sandoz, Novartis

\section{Dear Editor,}

The bibliometric analysis provided by Hernandez-Vasquez et al. [1] fills a gap in our knowledge of the growing literature in the field of biosimilars. One of the analyses conducted by the authors is identification of the top ten institutions publishing in biosimilars (Table 4). In this listing, Sandoz International is listed fifth, and Novartis International is listed tenth. Unfortunately, the authors may not be aware that Sandoz International and Novartis International are both divisions of one company - Novartis AG. Sandoz/Novartis should therefore be viewed as a single institution as scientists from the different divisions of Novartis work together as a single fully integrated biosimilars team.

With this clarification, when one adds the 33 publications ascribed to Sandoz and the 19 publications ascribed to Novartis, the resulting 52 would place Sandoz/ Novartis first, just ahead of Amgen.

Unfortunately, it is not clear from Hernandez-Vasquez et al. if each publication is scored only once, using the institutional affiliation of the first or corresponding author, or if a given publication could be scored more than once if multiple institutions are listed. Were the latter to be the case and if Sandoz and Novartis were both listed on a single publication, the combined Sandoz/Novartis score would be lower.

Correspondence: hillel.cohen@sandoz.com

Sandoz Inc., 100 College Road West, Princeton, NJ 08540, USA
In addition, combination of Sandoz and Novartis would lead to nine line listings on Table 4 instead of the desired ten.

Since we do not have access to the underlying data, we look forward to the authors providing an updated Table 4.

Sandoz/Novartis has been the pioneer in biosimilars since the inception of the industry. We began developing biosimilars in the 1990s, leading to the very first European, Japanese and US biosimilar approvals [2-4]. It is therefore not surprising that Sandoz/Novartis is among the leaders in publications within this nascent field.

Hillel P. Cohen.

Authors' contributions

The author read and approved the final manuscript.

\section{Authors' information}

HPC is an employee of Sandoz Inc. based in the USA and owns stock in Novartis.

Ethics approval and consent to participate

The Letter to the Editor does not contain patient data; therefore, ethics approval and consent for publication is not relevant.

Competing interests

HPC has no other competing interests.

\section{Publisher's Note}

Springer Nature remains neutral with regard to jurisdictional claims in published maps and institutional affiliations. 
Received: 9 May 2018 Accepted: 8 June 2018

Published online: 16 July 2018

\section{References}

1. Hernandez-Vasquez A, Alacron-Riuz CA, Bendezu-Quispe G, Comande D, Rosselli D. A bibliometrc analysis of global research on biosimilars. J Pharm Policy Practice. 2018;11:6-14.

2. European Medicines Agency. Omnitrope ${ }^{\bullet}$ summary of product characteristics. Available from: http://www.ema.europa.eu/docs/en_GB/ document_library/EPAR_-_Product_Information/human/000607/ WC500043695.pdf (accessed 23 Apr 2018).

3. Pharmaceuticals and Medical Devices Agency. PMDA perspective: recent trends in the regulation of biopharmaceuticals. Available from: http://www. pmda.go.jp/files/000197722.pdf\#page=24 (accessed 23 Apr 2018).

4. Food and Drug Administration. Zarxio ${ }^{\oplus}$ package insert. Available from: https://www.accessdata.fda.gov/drugsatfda_docs/label/2015/125553lbl.pdf (accessed 23 Apr 2018).

Ready to submit your research? Choose BMC and benefit from:

- fast, convenient online submission

- thorough peer review by experienced researchers in your field

- rapid publication on acceptance

- support for research data, including large and complex data types

- gold Open Access which fosters wider collaboration and increased citations

- maximum visibility for your research: over $100 \mathrm{M}$ website views per year

At BMC, research is always in progress.

Learn more biomedcentral.com/submissions 